\title{
EVALUATION OF STABILITY STRENGTH FOR DECK-TYPE STEEL ARCH BRIDGES
}

Tetsuya YABUKI* and Shigeru KURANISHI**

\begin{abstract}
Stability strengths of stiffened deck-type arch bridges have the potential to assist designers in better understanding the ultimate strength behavior of arch bridges, thus leading to the more economical, rational, and reliable arch bridge structures. Instabilities of overall buckling and local member buckling are examined in this paper. Based on the concept from limit state philosophy, a new reliable design equation is proposed which satisfied all the stipulated in the deck-type steel arch bridges.
\end{abstract}

Key Words : steel arch, limit state design criteria, ultimate strength

\section{INTRODUCTION}

Theories on stabilities of arch structural systems have been well established recently; fundamental analytical methods of them have been comprehensively presented by many authors ${ }^{1)-8)}$. These powerful procedures help in understanding fundamental characteristics of the ultimate strengths of deck-type steel arch bridge structural systems ${ }^{6)-8)}$. Nowadays, limit state philosophy tends to replace allowable stress theory in most bridge design codes ${ }^{9,10)}$. Therefore, such benefits would be particularly expected as could assist the designer in better understanding limit state design criteria for the arch bridge structures and lead to a more rational and economical final design. The practical formulations on the ultimate strength design criteria have been studied for stiffened deck-type steel arches ${ }^{11,12}$. Ref.11) gives the formula on only the overall instability for two hinged arches. Ref.12) has been carried out on the local instability of two hinged arch rib, but the restrictive effects produced by the adjacent panels were not considered. Therefore, it is expected that the design criteria, which could broadly, practically, and rationally apply to the deck type arch bridges, are specified.

When designing the stiffened deck-type arch bridge strucutre, we must ensure that the structure is safe against its overall instability and that there is no local member failures in a panel of the structural systems. In this paper, the design criteria for these

* Member of JSCE, Dr. Eng., Professor, Department of Civil Engineering, University of Ryukyu (Okinawa, Japan)

** Member of JSCE, Dr. Eng., Professor, Department of Civil Engineering, Tohoku University (Sendai, Japan) requirements, which could broadly, practically and rationally apply to the bridge structure with two-hinged and/or fixed supports, are proposed with a form of design interaction equation for the overall failure and a form of strength reduction factor for the local instability. The first part of this paper reviews briefly the ultimate strength characteristics to highlight particular features of the stability strengths of the bridge structures. This is followed with the exact solution of the ultimate strength calculated with an accurate nonlinear finite element approach, which is originally developed by the first author ${ }^{2}$. The same analysis has been adopted in Refs. 3), 4), 5), 6), 8) and 11). It is assumed that no out-of-plane deformation occurs anywhere in the structure and the ultimate strength is governed by instability failure in the vertical plane. The plates composing cross sections of the structural members are assumed not to fail prematurely by local plate bucklings. It is found that the proposed criteria are sufficiently accurate for practical applications to stiffened deck-type arch bridge systems.

\section{DESCRIPTION OF BRIDGE MOD- EL}

The arch bridge structural model considered in this study has an arch rib, a deck girder, and connecting elements between them (i.e., posts). The model is illustrated in Fig.1 and its properties are also listed in the figure. Notations used are as follows ; $L=$ span length, $R=$ rise of arch rib, $h_{a, b}=$ depth of cross section, $b_{a, d}=$ width of cross section, $t_{a, d, f, w}=$ thickness of a plate composing cross section, $A_{a, f, w}=$ cross sectional area of a plate composing arch rib cross section, $F_{Y}=$ yield stress level of material, subscript $a, d, f$, and $w=$ 
structural property of arch rib, deck girder, flange and web, respectively. The arch rib has a symmetric parabolic axial configuration and a constant box-shaped cross section with a welding residual stress distribution idealized as shown in Fig.1. The rib and the deck girder over it are connected intermittently, at the panel points, by the posts with hinged-hinged ends. The deck girder rests on rollers at its ends, where the uplifting is restrained, and is rigidly connected with the rib at its crown. Thus, the deck girder has no constraining against movement of the arch rib in direction of its span length. The deck girder is of a constant I-shaped cross section. The idealized distribution of welding residual stresses in the I-shaped cross section is also shown in Fig.1. The girder has the same material as the arch rib. Cross sectional area of the posts is chosen so as to avoid their premature failures. Usually, the deck system consists of a reinforced concrete slab connected by shear studs to steel stringers, which is turned, supported by the deck girders at the panel points. Considering such structural detail of the deck system, the model is loaded by a series of concentrated loads at each panel point. The load acting at each panel point on the left half of the structure is $q$ and that on the right half is $r q$; herein $r$ is termed load distributive parameter.

The ultimate strength analysis is carried out with a nonlinear finite element procedure. This approach takes into consideration spread of yielding, unloading and reloading of the yielded parts in the cross section and along the length, and the residual stress due to welding. Effects of finite deformations are also included. The load versus deformation relationship of the arch bridge structure model is obtained by successively incrementing the load until the maximum value is reached. For the each load increment, the tangent stiffness method and the Newton-Raphson iterative procedure are used and $0.1 \%$ of its accuracy is ensured. Namely, in each iteration, when the norm of the residual displacements is less than $0.1 \%$ of that of total displacements and the same condition is required by the unbalanced residual forces also, convergence for the equilibrium condition of the system is assumed to have been achieved. In all the numerical calculations, the arch and the deck girder are longitudinally divided into 8 equal segments in each panel, respectively. Elements of tangent stiffness matrix in the analysis are evaluated numerically, by dividing the cross section of arch rib into 36 segments and the deck girder into 27 segments, by referring the results of preexaminations $^{8,111}$.

The structural parameters examined in the study

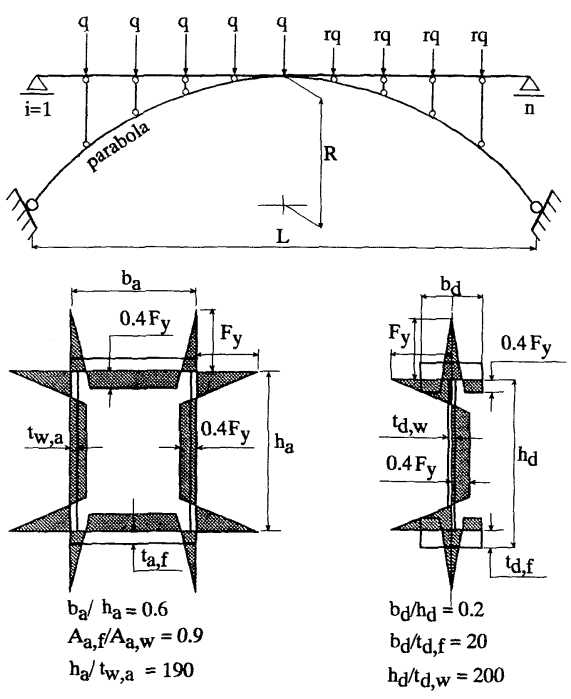

Fig.1 Arch Geometry and Loading

are; the rise-to-span ratio $R / L$, the slenderness ratio of the entire structural system of the arch bridge $\lambda_{T}$, which is defined by the ratio of the curvilinear length of the arch rib axis to the square root of $\left(I_{d}+I_{a}\right) / A_{a} ; I_{d, a}$ is the second moment of area, the flexural stiffness ratio of deck girder to arch rib $I_{d} / I_{a}$, the load distributive parameter $r$, the material strength parameter $\varepsilon_{Y}=F_{Y} / E ; E$ is Young's modulus $\left(=2.1 \times 10^{5} \mathrm{~N} / \mathrm{mm}^{2}\right)$, and the number of panels. The ranges of six parameters selected are given below;

$$
\begin{aligned}
& R / L=0.1 \sim 0.3 ; \lambda_{T}=100 \sim 300 ; I_{d} / I_{a}=0.1 \sim 10 ; \\
& r=0 \sim 0.99 ; \varepsilon_{Y}=0.0024 / 2.1 \sim 0.0046 / 2.1 ;
\end{aligned}
$$$$
\text { number of panels }=6 \sim 20
$$

They are generally within those found in existing arch bridges.

\section{BEHAVIOR AND INSTABILITY}

A total of 300 cases as listed in Table 1 were parametrically studied in this paper to instability, of which 252 were for the overall instabilities and the rest for the local ones. Typical results of the instability deformation modes with $\lambda_{T}=200, R / L$ $=0.15, r=0.99,6$-panels and two-hinged supports for a stocky arch rib type $\left(I_{d} / I_{a}=0.1\right)$ and a slender one $\left(I_{d} / I_{a}=10\right)$ are shown in Fig.2. In the figure, the applied load $q$ is nondimensionalized with respect to a reference load $q_{p}$ and in what follows, similar nondimensionalizing is adopted. This load, when applied at all the panel points of the arch rib, will cause full yielding of the springings under axial thrust. It is given by : 
Table 1 Cases of Paramertic Studies

\begin{tabular}{|c|c|c|c|c|c|c|c|}
\hline$\varepsilon_{\mathrm{Y}}$ & $\mathrm{R} / \mathrm{L}$ & $\lambda_{\mathrm{T}}$ & $\mathrm{I}_{d} / \mathrm{I}_{\mathrm{a}}$ & I & Panels & Supports & Cases \\
\hline $0.0032 / 2.1$ & 0.15 & $\begin{array}{l}100 \\
150 \\
200 \\
300\end{array}$ & $\begin{array}{l}0.1 \\
1.0 \\
10.0\end{array}$ & $\begin{array}{l}0 \\
0.5 \\
0.99\end{array}$ & $\begin{array}{l}10 \\
20\end{array}$ & $\begin{array}{l}\text { Hinged } \\
\text { Fixed }\end{array}$ & 144 \\
\hline $0.0032 / 2.1$ & $\begin{array}{l}0.1 \\
0.2 \\
0.3 \\
\end{array}$ & 200 & $\begin{array}{l}0.1 \\
1.0 \\
10.0 \\
\end{array}$ & $\begin{array}{l}0 \\
0.5 \\
0.99 \\
\end{array}$ & 20 & $\begin{array}{l}\text { Hinged } \\
\text { Fixed }\end{array}$ & 54 \\
\hline $\begin{array}{l}0.0024 / 2.1 \\
0.0036 / 2.1 \\
0.0046 / 2.1\end{array}$ & 0.15 & 200 & $\begin{array}{l}0.1 \\
1.0 \\
10.0 \\
\end{array}$ & \begin{tabular}{|l}
0 \\
0.5 \\
0.99 \\
\end{tabular} & 20 & $\begin{array}{l}\text { Hinged } \\
\text { Fixed }\end{array}$ & 54 \\
\hline $0.0032 / 2.1$ & 0.15 & $\begin{array}{l}100 \\
150 \\
200 \\
300\end{array}$ & $\begin{array}{l}0.1 \\
1.0 \\
10.0\end{array}$ & 0.99 & $\begin{array}{l}6 \\
8\end{array}$ & $\begin{array}{l}\text { Hinged } \\
\text { Fixed }\end{array}$ & 48 \\
\hline
\end{tabular}

$$
q_{p}=\frac{F_{Y} \cdot A}{\sqrt{\left\{\frac{n-2}{2}\right\}^{2}+\left\{\sum_{i=1}^{n}+\frac{5 L}{8 R} l_{1} l_{2}\left(l_{1}^{2}+3 l_{1} l_{2}+l_{2}^{2}\right)\right\}^{2}}}
$$

in which $n=$ total number of panel points including the end supports, $l_{1}=(i-1) /(n-1), l_{2}=1-l_{1}$, and $i=$ order of panel point, as shown in Fig.1. Fig.2 (a) shows typical deformation mode of the overall instability with primary buckling mode for the stocky type and Fig.2 (b) the interactive instability of the structural buckling with secondary mode and local member buckling for the slender type. It can be seen from the figure that the instability behavior remarkably varies with the stiffness ratio of deck girder to arch rib, even if their entire structural slenderness ratio is a certain value, and also seen that the local member failure initiates in the end panel.

The difference in the instability deformation modes will be clear from the bending moment diagrams shown in Fig.3, also. In the figure, the bending moment is nondimensionalized by the yield bending moment of arch rib $M_{a, Y}$. Since the arch rib has an axis curved continuously corresponding to the parabolic form, local bending moments are generated by offsets given by the curved configuration in a panel. It can be visualized that the arch rib in a panel of a deck-type arch bridge system, locally behaves a beam-column member model having an initial out-of-straightness from a line connecting with adjacent post locations (panel points) as shown in Fig.4. This initial out-of-straightness generates an additional bending moment in each panel of the arch rib (hereafter, this behavior will be termed beamcolumn model effect). A half wave mode which the moment diagrams show in the each panel is produced by this additional moment. As the result,
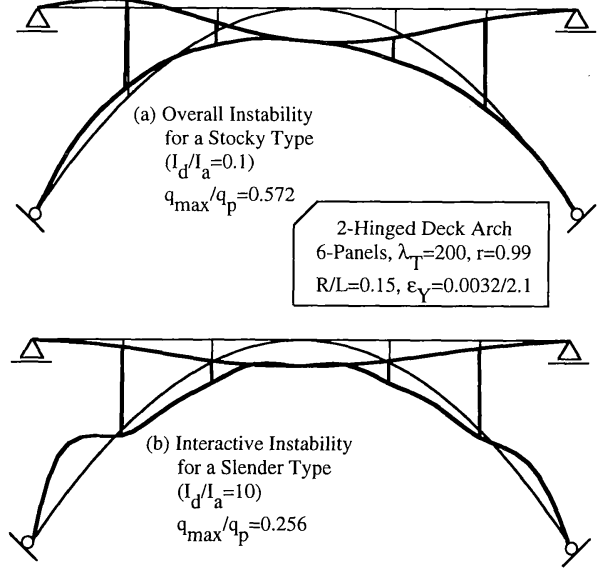

Fig.2 Typical Instability Deformation Modes

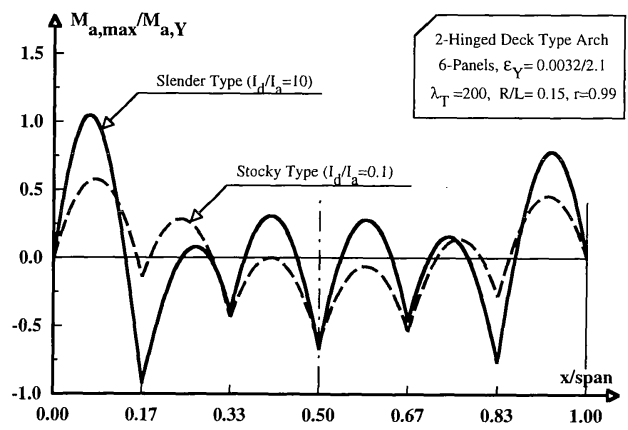

Fig.3 Bending Moment Diagrams

the local member buckling is apt to produce in a panel, especially in the end panel of deck-type arch bridge system with the slender beam-column element; i.e., the slender arch rib type with the long distance between the adjacent posts. As a matter of fact, the bending moment in the case of interactive instability has its maximum value in the end panel as shown in Fig.3.

The resultant bending moment versus axial thrust relationships at the quarter and the springing points of 2-hinged arch ribs corresponding to the reference cases of Fig.2 are given in Fig.5, where those resultant forces are nondimensionalized by their yield forces $N_{Y}$ and $M_{a, Y}$ for the arch rib cross section. The resultant relationship shows until the ultimate stability state is reached. It can be seen from the figure that the resultant bending moment increases normaly as the axial thrust increases, except at the quarter point of the slender arch rib type. It is noticed that decrease in the bending moment at the quarter point of the slender type with increase of the axial thrust synchronizes with showing nonlinear behavior. This behavior corresponds to the restrictive effect produced by the 
deflection of the beam-column model in the adjacent end panel.

Some selected results of the instability studies are shown in Fig.6, where the load-deflection relationships at a quarter point of an arch rib with $\lambda_{T}=200, R / L=0.15,6$-panels, and 2-hinged supports for a stocky arch rib type $\left(I_{d} / I_{a}=0.1\right)$ and a slender one $\left(I_{d} / I_{a}=10\right)$. For comparison purpose, the results of the elastic instability analysis are also shown, in which the geometric nonlinearity produced by prebuckling deformation is only taken into account. These results are shown as the dashed curves. The results of the inelastic instability analysis ${ }^{8)}$ are given by solid curves and show the true instability behavior of the structures. The linear bifurcation buckling load specified by the Japanese Highway Bridge Specifications ${ }^{13)}$ is comparatively referred. It is clear from Fig. 6 that the maximum load $q_{\max }$ of the slender type is lower than that of the stocky type. This discrepancy is caused by the interactive effect of the local member buckling. The true ultimate stability strength of the arch bridge is the maximum load $q_{\max }$ of the inelastic analysis and is generally much lower than the elastic values. It became evident after elastic analyzing that the elastic limit load, which shows the load level giving the initiation of material yield in the structural system (no residual stresses considered), is not able to evaluate the ultimate strength even though considering the effect of the finite deformations. Comparison of the ultimate strength with the elastic reference loads is described in more detail in Ref.8).

Variations of the ultimate strengths, $q_{\max } / q_{p}$ are shown in Fig.7 for fixed supports as a function of the slenderness ratio of the entire structural system of the deck-type arch bridges $\lambda_{T}$, for various values of the flexural stiffness ratio $I_{d} / I_{a}$ and the load distributive parameter $r$. As is obvious from Fig.7, the ultimate strength decreases with increasing the slenderness ratio and it should be one of the important factors to predict the ultimate strength. From Fig.7 it is seen that the quasi-symmetric loading (i.e., $r=0.99$ ) causes a certain difference between the ultimate strengths for a stocky arch rib type $\left(I_{d} / I_{a}=0.1\right)$ and a slender type $\left(I_{d} / I_{a}=10\right)$, while in the asymmetric loading there is no significant differences between the two. The differences for the several values of $\lambda_{T}, I_{d} / I_{a}, r$ and number of panels are typically given in Table 2 , where the hinged and fixed arch bridges have identical geometric and material properties. The ultimate stability strength decreases with increasing the slenderness ratio $\lambda_{T}$. The increase in the overall instability strength of the stocky type arch bridge over the slender type bridge is generally confirmed

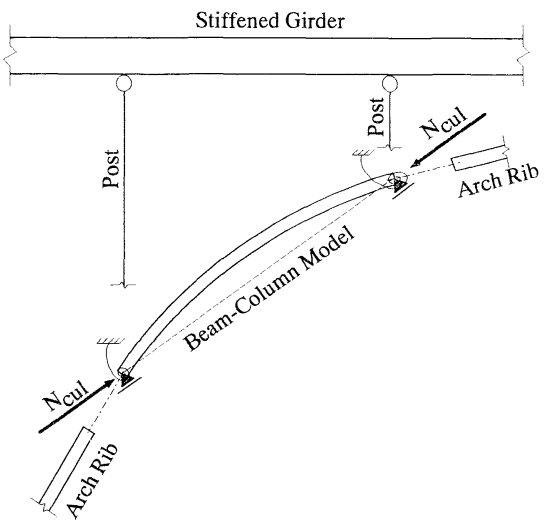

Fig.4 Beam-Column Member Model

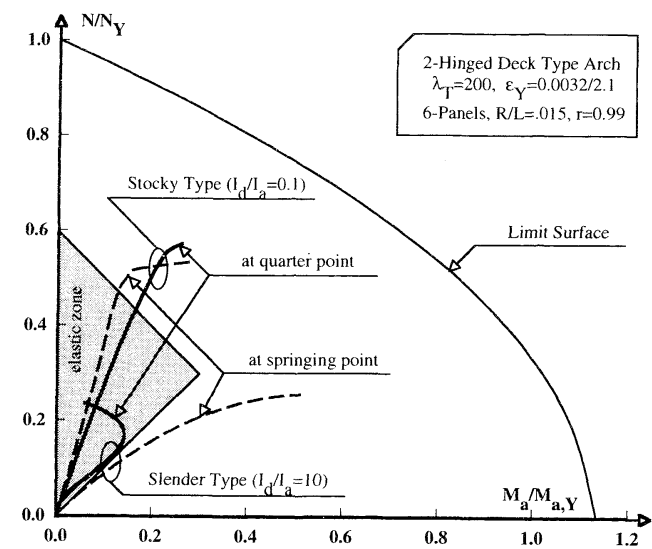

Fig.5 Resultant Bending Moment vs. Axial Thrust Relationships

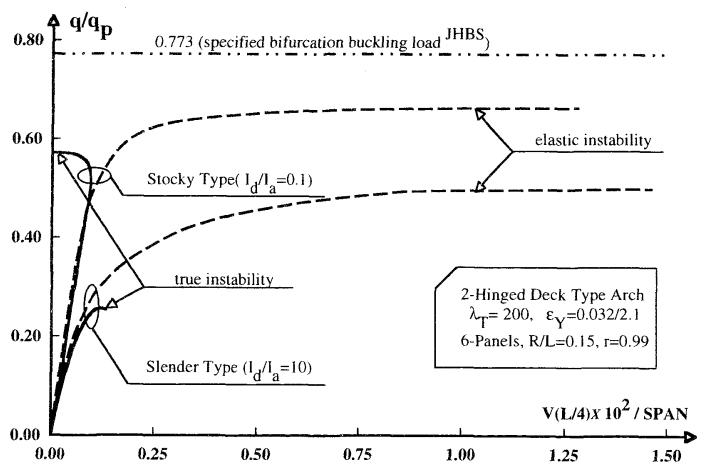

Fig.6 Load-Deflection Curves at Quarter Point of Arch Rib

in the fixed arch bridges, while the decrease in the strength is in the hinged ones. It can be seen that the local member buckling phenomenon occurs in the slender type bridges with 6,8 , and 10 panels under the quasi-symmetric loading, while no local buckling occurs in the 20-panel arch bridges and all 


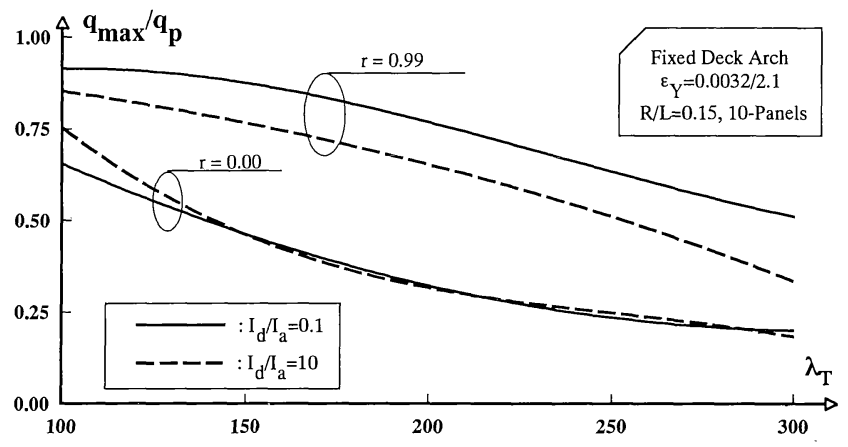

Fig.7 Relationship between $q_{\max } / q_{p}$ and $\lambda_{T}$

Table 2 Nondimensional Ultimate Stability Load $q_{\max } / q_{p}$ of Hinged and Fixed Deck Arch Bridge

\begin{tabular}{|c|c|c|c|c|c|c|c|c|c|c|}
\hline \multirow{2}{*}{$\lambda_{\mathrm{T}}$} & \multirow[b]{2}{*}{$\mathrm{I}_{\mathrm{d}} / \mathrm{I}_{\mathrm{a}}$} & \multirow[b]{2}{*}{$\mathbf{r}$} & \multicolumn{2}{|c|}{ 20-Panels } & \multicolumn{2}{|c|}{ 10-Panels } & \multicolumn{2}{|c|}{ 8-Panels } & \multicolumn{2}{|c|}{ 6-Panels } \\
\hline & & & Hinged & Fixed & Hinged & Fixed & Hinged & \begin{tabular}{|l|} 
Fixed \\
\end{tabular} & Hinged & Fixed \\
\hline 100 & $\begin{array}{l}0.1 \\
10\end{array}$ & \begin{tabular}{|l}
0.5 \\
0.99 \\
0.5 \\
0.99 \\
\end{tabular} & $\begin{array}{l}0.637 \\
0.980 \\
0.991 \\
0.975 \\
\end{array}$ & \begin{tabular}{|l|}
0.799 \\
0.980 \\
1.022 \\
0.980 \\
\end{tabular} & $\begin{array}{l}0.632 \\
0.916 \\
0.940 \\
0.816(\mathrm{~L}) \\
\end{array}$ & $\begin{array}{l}0.778 \\
0.916 \\
0.918 \\
0.854 \\
\end{array}$ & $\begin{array}{l}0.900 \\
0.700(\mathrm{~L})\end{array}$ & $\begin{array}{l}0.914 \\
0.803(\mathrm{~L})\end{array}$ & $\begin{array}{l}0.809 \\
0.600(\mathrm{~L})\end{array}$ & $\begin{array}{l}0.856 \\
0.700(\mathrm{~L})\end{array}$ \\
\hline 200 & $\begin{array}{l}0.1 \\
10\end{array}$ & \begin{tabular}{|l|}
0.5 \\
0.99 \\
0.5 \\
0.99 \\
\end{tabular} & $\begin{array}{l}0.307 \\
0.592 \\
0.380 \\
0.658 \\
\end{array}$ & $\begin{array}{l}0.462 \\
0.880 \\
0.429 \\
0.772 \\
\end{array}$ & $\begin{array}{l}0.296 \\
0.536 \\
0.369 \\
0.556(L) \\
\end{array}$ & $\begin{array}{l}0.447 \\
0.800 \\
0.409 \\
0.653(\mathrm{~L}) \\
\end{array}$ & $\begin{array}{l}0.589 \\
0.403(\mathrm{~L})\end{array}$ & $\begin{array}{c}0.768 \\
0.600(L)\end{array}$ & $\begin{array}{l}0.572 \\
0.256(\mathrm{~L})\end{array}$ & $\begin{array}{l}0.717 \\
0.400(\mathrm{~L})\end{array}$ \\
\hline 300 & $\begin{array}{l}0.1 \\
10\end{array}$ & $\begin{array}{l}0.5 \\
0.99 \\
0.5 \\
0.99 \\
\end{array}$ & $\begin{array}{l}0.176 \\
0.288 \\
0.201 \\
0.299 \\
\end{array}$ & $\begin{array}{l}0.290 \\
0.575 \\
0.229 \\
0.400 \\
\end{array}$ & $\begin{array}{l}0.162 \\
0.284 \\
0.195 \\
0.293(\mathrm{~L})\end{array}$ & $\begin{array}{l}0.269 \\
0.541 \\
0.220 \\
0.333(\mathrm{~L}) \\
\end{array}$ & $\begin{array}{l}0.286 \\
0.240(\mathrm{~L})\end{array}$ & $\begin{array}{l}0.510 \\
0.308(\mathrm{~L})\end{array}$ & $\begin{array}{l}0.283 \\
0.140(\mathrm{~L})\end{array}$ & $\begin{array}{l}0.506 \\
0.231(\mathrm{~L})\end{array}$ \\
\hline
\end{tabular}

Note: Deck Type Arch Bridge, $\mathrm{R} / \mathrm{L}=0.15, \varepsilon_{\mathrm{Y}}=0.0032 / 2.1,(\mathrm{~L})=$ with local member failure.

of their collapses show the overall instability failure with the fundamental instability mode.

\section{ULTIMATE STRENGTH DESIGN CRITERIA}

\section{(1) Overall instability failures}

The extensive numerical results obtained from the study make, broadly and practically, the development of an ultimate strength design procedure for the overall instability failures and local member bucklings in the stiffened deck type arch bridge structures. First, a design aid for the overall failure is proposed. This procedure permits direct use of the design criteria, which have been proposed previously for an arch rib ${ }^{3,5)}$, and thus is more convenient in bridge engineering practice. The practical formulation previously proposed for evaluating the ultimate strength of an arch is expressed in terms of the axial thrust, $N_{\max }$, and bending moment, $M_{\max }$, at the critical quarter point determined from a linear analysis at the ultimate load of the arch. They are as follows;

$$
\begin{gathered}
a \cdot\left[\frac{K \cdot M_{\max }}{M_{Y}}\right]^{2}+b\left[\frac{K \cdot M_{\max }}{M_{Y}}\right]+c \cdot\left[\frac{N_{\max }}{N_{Y}}\right]=1 \\
\text { for } \frac{N_{\max }}{N_{Y}} \geq n_{c r}
\end{gathered}
$$

$$
\begin{array}{r}
\alpha \cdot\left[\frac{K \cdot M_{\max }}{M_{Y}}\right]+\beta \cdot\left[\frac{N_{\max }}{N_{Y}}\right]=1 \\
\text { for } \frac{N_{\max }}{N_{Y}}<n_{c r}
\end{array}
$$

where $a, b, c, \alpha$ and $\beta$ are empirical coefficients and $n_{c r}$ are depending on the rise-to-span ratio and slenderness ratio parameter.

Namely;

$$
\begin{aligned}
\bar{\lambda}= & \frac{K}{\pi} \cdot \sqrt{\frac{F_{Y}}{E}} \cdot \lambda \\
K= & 1 \text { for } 2 \text {-hinged arch } \\
= & 0.716-0.249 R / L \text { for fixed } \operatorname{arch}^{5)} \\
a= & 2.509-1.689 \bar{\lambda} ; b=-1.213+1.605 \bar{\lambda} \\
& -0.135 \bar{\lambda}^{2} \\
c= & \left(1.824-0.914 \bar{\lambda}+0.376 \bar{\lambda}^{2}\right)(0.82+1.2 R / L) ; \\
\alpha= & 1 / m_{p} ; \beta=\left(m_{p}-m_{c r}\right) /\left(m_{p} \cdot n_{c r}\right) \\
m_{p}= & (1.023-0.041 \bar{\lambda}) \cdot M_{p} / M_{Y} ; \\
n_{c r}= & \left(1-b \cdot m_{c r}-a \cdot m_{c r}^{2}\right) / c ; \\
m_{c r}= & m_{p} \text { for }\left(a \cdot m_{p}^{2}+b \cdot m_{p}-1\right) / a \leq 0 ; \\
= & m_{p}-\sqrt{\left(a \cdot m_{p}^{2}+b \cdot m_{p}-1\right) / a} \\
& \quad \text { for }\left(a \cdot m_{p}^{2}+b \cdot m_{p}-1\right) / a>0 . \cdots \cdots \ldots(2 . b)
\end{aligned}
$$


where $M_{p}=$ full plastic bending moment for reference arch cross-section. When applying Eqs.2 to a fixed arch, the designer should adopt the $M_{\max }$ and $N_{\max }$ obtained by converting end-supports of the reference arch from the fixed condition to two-hinged one, provided that the ultimate load is the maximum load carrying capacity for the reference fixed $\operatorname{arch}^{5)}$.

As obvious from Fig.2(a), the deformation mode at the ultimate state for the overall failure shows that the deck and the arch rib act as so-called superposed beam components. The bending moments acting on the stiffened deck girder and the arch rib can be evaluated approximately by distributing the total bending moments in proportion to their moments of inertia or their flexural rigidities. Therefore, we may establish an equivalent arch which has the same ultimate stability strength as the reference deck type arch bridge structure. The analytical study of the deck-type bridge structures shows that the maximum bending moment $M_{\max }$ and yield bending moment $M_{Y}$ of the equivalent arch might be evaluated as follows:

$$
\frac{M_{\max }}{M_{Y}}=\frac{M_{a, \max }+M_{d, \max }}{M_{a Y}+M_{d Y}}
$$

in which $M_{a, \max }, M_{d, \max }=$ the bending moment at a critical quarter point of the each structural component (arch rib and deck girder) determined from a linear analysis at the ultimate load of the bridge structure; $M_{a, Y}, M_{d, Y}=$ the yield bending moment of the each structural member. The nondimensional maximum normal thrust $N_{\max } / N_{Y}$ of the equivalent arch is the same as that of the reference arch rib. It is proposed to use the same maximum values $N_{\max } / N_{Y}$ and $M_{\max } / M_{Y}$ given by Eq.(3) to define the equivalent arch. When applying Eqs.(2) to the fixed arch bridge structure, the user should adopt the same manner as previously described, provided that the effect of simple supports of the deck girder should be considered in the slenderness ratio of the equivalent arch. Namely, since only arch ribs have fixed end supports in the fixed arch bridge, the equivalent arch should have the slenderness ratio parameter evaluated as follows :

$$
\begin{aligned}
\bar{\lambda} & =\frac{\lambda_{T}}{\pi} \cdot \sqrt{\frac{F_{Y}}{E}} \text { for 2-hinged arch bridge } \\
& =\frac{\lambda_{a}}{\pi} \cdot \sqrt{\frac{F_{Y}}{E}} \cdot \frac{K}{\sqrt{1+K^{2} I_{d} / I_{a}}}
\end{aligned}
$$$$
\text { for fixed arch bridge. }
$$

where $\lambda_{a}$ is the slenderness ratio of the arch rib and defined by the ratio of the curvilinear length of the arch rib axis to the radius of gyration of the arch rib.

Therefore, the ultimate strength for overall instability of deck-type arch bridge structure can be predicted directly by applying Eqs.(2) to the equivalent arch. In order to confirm the applicability of these design aid equations, their results and those by the ultimate strength analysis for the overall instabilities of the bridge structures are compared by varying the rise-to-span ratio $R / L$, the slenderness ratio of entire structural system of the arch bridge $\lambda_{T}$, the flexural stiffness ratio of deck girder to arch rib $I_{d} / I_{a}$, the load distributive parameter $r$, the material strength parameter $\varepsilon_{Y}$ and the support condition of bridge structure. The accuracy of the proposed formula in predicting the ultimate strength for overall instability of deck type arch bridges is demonstrated in Fig.8 on typical examples for various values of $I_{d} / I_{a}$ for 2-hinged and fixed types as a function of $R / L$. The analytically determined values are presented by the symbolized marks, and the values drawn with heavy curves indicate the predicted results. Additional results for a range of values of $I_{d} / I_{a}, r$ and panel number are given in Table 3 for 2-hinged arch bridges, where columns (4) and (8) show the ultimate load intensity calculated by the ultimate-strength-analysis, (5), (6), (9) and (10) express the maximum member forces at a quarter point of arch rib determined from a linear analysis at the calculated ultimate load $q_{\max ^{\prime}}$ and (7) and (11) give the coefficient of accuracy defined by ratio of the calculated maximum force to the predicted one. The applicability of the proposed formula is also checked by varying the material strength. The typical results are listed in Table 4 for 2-hinged and fixed types, where the notations used are similar to those of Table 3. The coefficients of accuracy for 252 cases for the overall instability studied herein are gathering between 0.732 and 1.095 for 2-hinged types, and 0.690 and 1.110 for fixed types. The mean value and standard error are 0.939 and 0.007 for the 2-hinged types, and 0.967 and 0.009 for the fixed, respectively. It can therefore be concluded that the proposed formula can provide good estimates of the ultimate strengths for the overall instabilities of deck type arch bridges for use in design. It may be concluded that the evaluation of the overall strength using the equivalent arch concept proposed herein gives results be sufficiently accurate for practical applications.

\section{(2) Local member bucklings}

The analytical study of stiffened deck arch bridge structures having slender arch ribs with various values of panel numbers under the quasisymmetric loading shows that the decrease in 


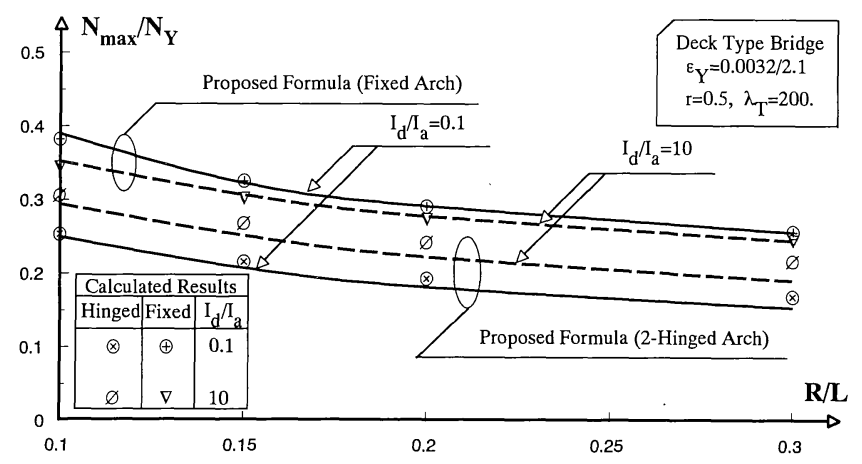

Fig.8 Comparison of Calculated Strength with Predicted One

Table 3 Comparison of Calculated Strength with Predicted One Based on Proposed Formula

\begin{tabular}{|c|c|c|c|c|c|c|c|c|c|c|}
\hline \multirow[b]{2}{*}{$\begin{array}{l}\lambda_{\mathrm{T}} \\
(1) \\
\end{array}$} & \multirow[b]{2}{*}{$\begin{array}{l}\mathrm{I}_{\mathrm{d}} / \mathrm{I}_{\mathrm{a}} \\
(2)\end{array}$} & \multirow[b]{2}{*}{ (3) } & \multicolumn{4}{|c|}{ 20-Panels } & \multicolumn{4}{|c|}{ 10-Panels } \\
\hline & & & $\begin{array}{l}q_{\max } / q_{p} \\
(4)\end{array}$ & $\begin{array}{l}\mathrm{N} / \mathrm{N}_{\mathrm{Y}} \\
(5)\end{array}$ & \begin{tabular}{|l}
$\mathrm{M} / \mathrm{M}_{\mathrm{Y}}$ \\
$(6)$
\end{tabular} & $\begin{array}{l}\omega \\
(7) \\
\end{array}$ & $\begin{array}{l}q_{\max } / q_{p} \\
(8)\end{array}$ & $\begin{array}{l}\mathrm{N} / \mathrm{N}_{\mathrm{Y}} \\
(9) \\
\end{array}$ & $\begin{array}{l}\mathrm{M} / \mathrm{M}_{\mathrm{Y}} \\
(10)\end{array}$ & $\begin{array}{l}\omega \\
(11) \\
\end{array}$ \\
\hline \multirow[t]{6}{*}{100} & 0.1 & 0.5 & 0.637 & 0.4454 & 0.6161 & 0.941 & 0.632 & 0.4542 & 0.5511 & 0.986 \\
\hline & & 0.99 & 0.980 & 0.8843 & 0.1388 & 0.828 & 0.916 & 0.8296 & 0.0688 & 0.914 \\
\hline & 1.0 & 0.5 & 0.753 & 0.5256 & 0.6238 & 0.861 & 0.739 & 0.5306 & 0.5523 & 0.907 \\
\hline & & 0.99 & 1.000 & 0.9014 & 0.1262 & 0.819 & 1.000 & 0.9046 & 0.0697 & 0.841 \\
\hline & 10.0 & 0.5 & 0.991 & 0.6901 & 0.6303 & 0.737 & 0.940 & 0.6734 & 0.5400 & 0.794 \\
\hline & & 0.99 & 0.957 & 0.8617 & 0.0963 & 0.868 & 0.816 & $(\mathrm{~L})$ & $(\mathrm{L})$ & (L) \\
\hline \multirow[t]{6}{*}{200} & 0.1 & 0.5 & 0.307 & 0.2161 & 0.5570 & 0.960 & 0.296 & 0.2141 & 0.4783 & 1.039 \\
\hline & & 0.99 & 0.592 & 0.5373 & 0.0754 & 0.873 & 0.536 & 0.4883 & 0.0151 & 1.059 \\
\hline & 1.0 & 0.5 & 0.337 & 0.2367 & 0.5212 & 0.947 & 0.321 & 0.2318 & 0.4417 & 1.031 \\
\hline & & 0.99 & 0.626 & 0.5684 & 0.0697 & 0.837 & 0.577 & 0.5260 & 0.0494 & 0.928 \\
\hline & 10.0 & 0.5 & 0.380 & 0.2671 & 0.4504 & 0.942 & 0.369 & 0.2666 & 0.3896 & 0.997 \\
\hline & & 0.99 & 0.658 & 0.5974 & 0.0574 & 0.815 & 0.556 & (L) & (L) & $(\mathrm{L})$ \\
\hline \multirow[t]{6}{*}{300} & 0.1 & 0.5 & 0.176 & 0.1244 & 0.4745 & 0.872 & 0.162 & 0.1170 & 0.3858 & 0.983 \\
\hline & & 0.99 & 0.288 & 0.2573 & 0.0426 & 0.949 & 0.284 & 0.2593 & 0.0222 & 0.983 \\
\hline & 1.0 & 0.5 & 0.187 & 0.1320 & 0.4296 & 0.876 & 0.173 & 0.1253 & 0.3520 & 0.973 \\
\hline & & 0.99 & 0.294 & 0.2672 & 0.0375 & 0.929 & 0.289 & 0.2641 & 0.0364 & 0.941 \\
\hline & 10.0 & 0.5 & 0.201 & 0.1416 & 0.3527 & 0.895 & 0.195 & 0.1413 & 0.3041 & 0.938 \\
\hline & & 0.99 & 0.299 & 0.2718 & 0.0296 & 0.933 & 0.293 & (L) & (L) & (L) \\
\hline
\end{tabular}

Note: 2 -Hinged Deck Type Arch, $\mathrm{R} / \mathrm{L}=0.15, \varepsilon_{Y}=0.0032 / 2.1,(\mathrm{~L})=$ with local member failure.

strength is due primarily to the local member buckling at the end panel, because of the interactive effect of the beam-column behavior described previously. Fig.9 shows some typical results of the ultimate axial thrust in the end panel of arch rib prone to local member buckling, $N_{\text {cul }}$, as a function of slenderness ratio parameter of the beam-column model as follows:

$$
\bar{\lambda}_{l}=\frac{1}{\pi} \cdot \sqrt{\frac{F_{Y}}{E}} \cdot \lambda_{l}
$$

where $\lambda_{l}$ is the slenderness ratio of the beamcolumn model (generally idealized by Fig.4) in the end panel and defined by the ratio of the beam-column model length to the radius of gyration of the arch rib. The axial thrust is nondimensionalized by $N_{Y}$. In the figure, the column strength, $N_{\text {column, }}$, and the beam-column strength, $N_{\text {beam-column }}$ specified by the Japanese Design Code of Steel Structures ${ }^{4)}$ are also shown for comparison purpose. These values are also nondimensionalized by $N_{Y}$. It is obvious from the figure that the specified column strength gives progressive estimation and the beam column strength too conservative. Thus, more rational design criteria for these local instabilities should be developed. A simple way to evaluate the behavior of the interactive effect is to use a strength reduction factor. The factor $\phi$ could be evaluated by the following equation:

$$
\phi=N_{\text {cul }} / N_{\text {cug }} \text {. }
$$

where $N_{\text {cug }}=$ the ultimate axial thrust at the end 
Table 4 Comparison of Calculated Strength with Predicted One Based on Proposed Formula

\begin{tabular}{|c|c|c|c|c|c|c|c|c|c|c|}
\hline \multirow[b]{2}{*}{$\varepsilon_{\mathrm{Y}}$} & \multirow[b]{2}{*}{$\mathrm{I}_{\mathrm{d}} / \mathrm{I}_{\mathrm{a}}$} & \multirow[b]{2}{*}{$\mathrm{r}$} & \multicolumn{4}{|c|}{ 2-Hinged Deck Type Arch Bridge } & \multicolumn{4}{|c|}{ Fixed Deck Type Arch Bridge } \\
\hline & & & $\mathrm{q}_{\max } / \mathrm{q}_{\mathrm{p}}$ & $\mathrm{N} / \mathrm{N}_{\mathrm{Y}}$ & $\mathrm{M} / \mathrm{M}_{\mathrm{Y}}$ & $\omega$ & $\mathrm{q}_{\max } / \mathrm{q}_{\mathrm{p}}$ & $\mathrm{N} / \mathrm{N}_{\mathrm{Y}}$ & $\mathrm{M} / \mathrm{M}_{\mathrm{Y}}$ & $\omega$ \\
\hline $0.0024 / 2.1$ & $\begin{array}{l}0.1 \\
10\end{array}$ & $\begin{array}{l}0.5 \\
0.99 \\
0.5 \\
0.99 \\
\end{array}$ & $\begin{array}{l}0.340 \\
0.722 \\
0.438 \\
0.782 \\
\end{array}$ & $\begin{array}{l}0.2397 \\
0.6562 \\
0.3076 \\
0.7817 \\
\end{array}$ & $\begin{array}{l}0.6180 \\
0.0921 \\
0.5187 \\
0.0752 \\
\end{array}$ & $\begin{array}{l}0.973 \\
0.841 \\
0.941 \\
0.732 \\
\end{array}$ & $\begin{array}{l}0.495 \\
0.910 \\
0.491 \\
0.886 \\
\end{array}$ & $\begin{array}{l}0.3485 \\
0.8266 \\
0.3447 \\
0.8047 \\
\end{array}$ & $\begin{array}{l}0.8984 \\
0.1161 \\
0.5813 \\
0.0774 \\
\end{array}$ & $\begin{array}{l}0.993 \\
0.871 \\
1.031 \\
0.765 \\
\end{array}$ \\
\hline $0.0036 / 2.1$ & $\begin{array}{l}0.1 \\
10\end{array}$ & \begin{tabular}{|l|}
0.5 \\
0.99 \\
0.5 \\
0.99 \\
\end{tabular} & $\begin{array}{l}0.293 \\
0.539 \\
0.357 \\
0.592 \\
\end{array}$ & $\begin{array}{l}0.2062 \\
0.4900 \\
0.2507 \\
0.5370 \\
\end{array}$ & $\begin{array}{l}0.5316 \\
0.0688 \\
0.4227 \\
0.0518 \\
\end{array}$ & $\begin{array}{l}0.950 \\
0.886 \\
0.938 \\
0.839 \\
\end{array}$ & $\begin{array}{l}0.449 \\
0.856 \\
0.403 \\
0.713 \\
\end{array}$ & $\begin{array}{l}0.3162 \\
0.7776 \\
0.2832 \\
0.6471 \\
\end{array}$ & $\begin{array}{l}0.8151 \\
0.1092 \\
0.4776 \\
0.0622 \\
\end{array}$ & $\begin{array}{l}1.006 \\
0.840 \\
1.011 \\
0.765 \\
\end{array}$ \\
\hline $0.0046 / 2.1$ & 10 & $\begin{array}{l}0.5 \\
0.99 \\
0.5 \\
0.99\end{array}$ & $\begin{array}{l}0.262 \\
0.462 \\
0.310 \\
0.465\end{array}$ & $\begin{array}{l}0.1848 \\
0.4200 \\
0.2175 \\
0.4208\end{array}$ & $\begin{array}{l}0.4764 \\
0.0590 \\
0.3667 \\
0.0406\end{array}$ & $\begin{array}{l}0.922 \\
0.865 \\
0.919 \\
0.894\end{array}$ & $\begin{array}{l}0.418 \\
0.773 \\
0.351 \\
0.593\end{array}$ & $\begin{array}{l}0.2944 \\
0.7022 \\
0.2463 \\
0.5381\end{array}$ & $\begin{array}{l}0.7590 \\
0.0986 \\
0.4153 \\
0.0517\end{array}$ & $\begin{array}{l}0.996 \\
0.845 \\
0.990 \\
0.776\end{array}$ \\
\hline
\end{tabular}

Note $: \lambda_{\mathrm{T}}=200, \mathrm{R} / \mathrm{L}=0.15,20$-Panels, Predicted Member Forces are $\left(\mathrm{N} / \mathrm{N}_{\mathrm{Y}}, \mathrm{M} / \mathrm{M}_{\mathrm{Y}}\right)$ multiplied by $\omega$

panel of a standard arch rib in which the local member buckling does not occur until the ultimate stability state of the reference structure is reached---- that is, the ultimate strenght is characterized by the aforementioned overall instability. A slender arch rib type with 20 panels stiffened by the deck girder under the quasisymmetric loading studied herein is adopted as the standard because the overall instability characterizes the ultimate stability strength of this type of the bridge system. If the reduction factor is expressed for the ultimate load intensity,

$$
\bar{\phi}=\bar{q}_{\text {max }}, \text { interact } / \bar{q}_{\max }, \text { overall } \cdots
$$

where $\bar{q}_{\text {max,overall }}=$ the intensity of the ultimate stability load of the standard arch bridge structure in nondimensional form by $q_{p}$ formulated by Eq. (1), and $\bar{q}_{\max \text {, interact }}=$ the nondimensional intensity of the load for the interactive ultimate stability in which the decrease in strength is due primarily to the local member buckling at the end panel. The arch bridge structural system for $\bar{q}_{\text {max, interact }}$ being calculated has all structural properties identical with the abovementioned standard one, except the number of panels, i.e., slenderness ratio of the beam-column model. The ultimate axial thrust on the arch rib is neary in proportion to the ultimate load intensity ${ }^{3,5,5,11)}$.

Namely;

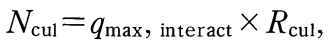

$$
\begin{aligned}
& N_{\text {cug }}=q_{\text {max }} \text {, overall } \times R_{\text {cug }} \text {. }
\end{aligned}
$$

where, by referring Fig.1,

$$
\begin{aligned}
& R_{\text {cul }}=\sqrt{\left\{\frac{n-2}{2}\right\}^{2}+\left\{\sum_{i=1}^{n} \frac{5}{8} \frac{L}{R} l_{1} l_{2}\left(l_{1}^{2}+3 l_{1} l_{2}+l_{2}^{2}\right)\right\}^{2}} \\
& \quad \text { for local instability case } \\
& R_{\text {cug }}=\sqrt{\left\{\frac{n-2}{2}\right\}^{2}+\left\{\sum_{i=1}^{\mathrm{n}} \frac{5}{8} \frac{L}{R} l_{1} l_{2}\left(l_{1}^{2}+3 l_{1} l_{2}+l_{2}^{2}\right)\right\}^{2}}
\end{aligned}
$$

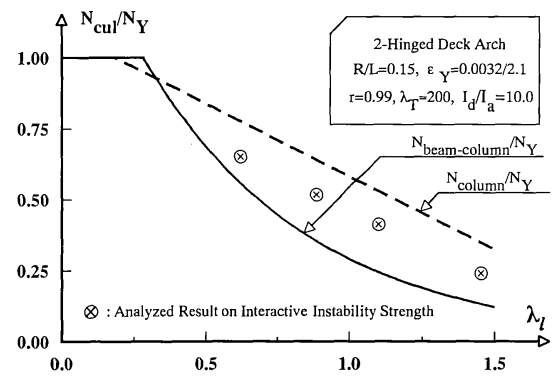

Fig.9 Ultimate Axial Thrust in the End Panel for Interactive Instability

for overall instability case

From Eqs. (1) and (8.b),

$$
\begin{aligned}
& \bar{q}_{\text {max }, \text { interact }}=q_{\text {max, interact }} \times R_{\text {cul }} /\left(F_{Y} \cdot A\right) \\
& \bar{q}_{\text {max, overall }}=q_{\text {max, overall }} \times R_{\text {cug }} /\left(F_{Y} \cdot A\right) \cdots \cdots(9)
\end{aligned}
$$

Therefore, from Eqs. (6), (7), (8) and (9), the relationship between $\bar{\phi}$ and $\phi$ is as follows;

$$
\bar{\phi}=\frac{q_{\mathrm{max}, \text { interact }}}{q_{\mathrm{max}, \text { overall }}} \times \frac{R_{\mathrm{cul}}}{R_{\mathrm{cug}}}=\phi
$$

The numerical results obtained in this study for the ultimate stability strength under the quasi-symmetric loading allow a practical formulation of $\phi$. By substituting the numerical results of $q_{\max }$, interact for 6-, 8- and 10-panel systems and of $q_{\max }$, overall for 20-panel obtained from the study, into Eq. (10), the factor $\phi$ is evaluated. Variation of $\phi$ is shown in Fig.10 for 2-hinged type and Fig.11 for fixed one as function of the slenderness ratio parameter of the beam-column model $\lambda_{l}$ for various values of the $\lambda_{T}$. It can be seen from Figs. (10) and (11) that the $\phi$ is proportional to $\lambda_{l}$. A point at which a line to plot the proportional function and a line of the $\phi$ $=1$ intersect depends on $\lambda_{T}$ and the range of $\lambda_{l}$ in which the proportional function applies is more 


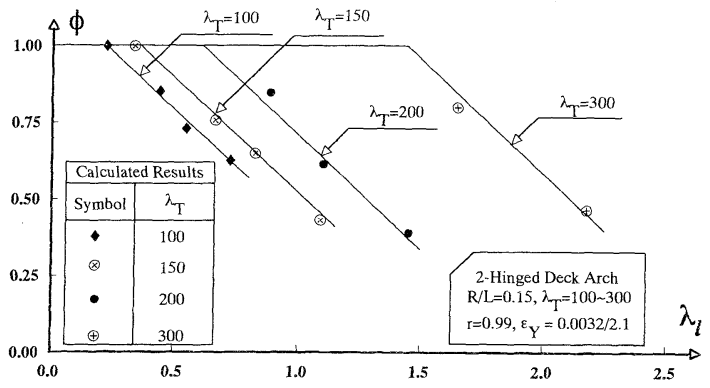

Fig.10 Variation of $\phi$ for Hinged Type

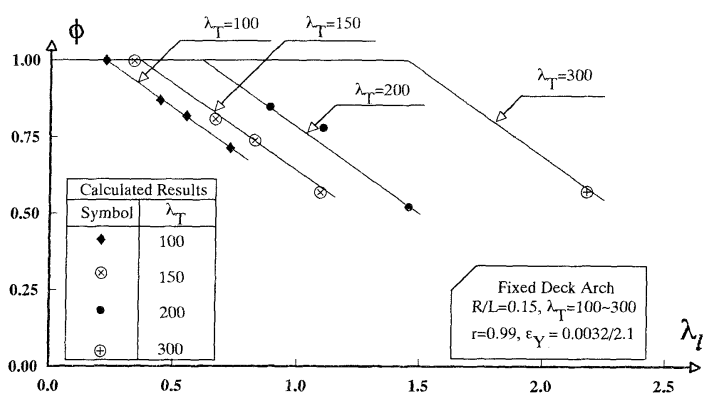

Fig.11 Variation of $\phi$ for Fixed Type

than or equal to the intersection point. This critical point is expressed herein as follows:

$$
\phi=1 ; \bar{\lambda}_{l}=\bar{\lambda}_{l, c r}
$$

Fig.12 shows variation of $\phi$ for various values of $R / L$ concerning with 2 -hinged and fixed types. From Fig.12, the abovementioned critical slenderness ratio parameter seems to be proportional to the $R / L$. By applying regression analysis to statistics of the broadly calculated results, a prediction formula for the $\phi$ can be obtained finally as follows:

$$
\begin{aligned}
& \phi=1-\gamma\left(\bar{\lambda}_{l}-\bar{\lambda}_{l, c r}\right) ; \\
& r=0.747 \text { for } 2-\text { hinged arch bridge } \\
&=0.566 \text { for fixed arch bridge; } \\
& \bar{\lambda}_{l, c r}=(1.261-1.737 R / L)\left(0.279-0.244 \bar{\lambda}_{T}\right. \\
&\left.\quad+0.144 \bar{\lambda}_{T}^{2}\right) .
\end{aligned}
$$

The effects of the boundary conditions, the initial curvature, and the interactive behavior on the local buckling are included eventually in the practical prediction formula given by $\mathbf{E q}$. (12). It is proposed to use Eq. (12) to evaluate the strength reduction factor $\phi$.

The accuracy of using the reduction factor defined by Eq. (12) in predicting the ultimate interactive stability strength of a stiffened deck type arch bridge structure is also illustrated in Fig.10, Fig.11 and Fig.12. The solid lines show

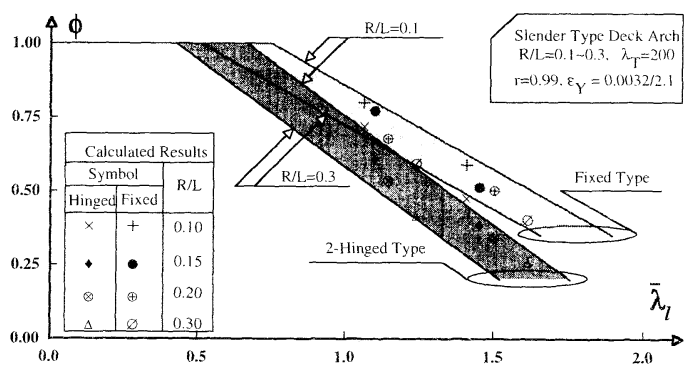

Fig.12 Effect of $\mathrm{R} / \mathrm{L}$ on $\phi$

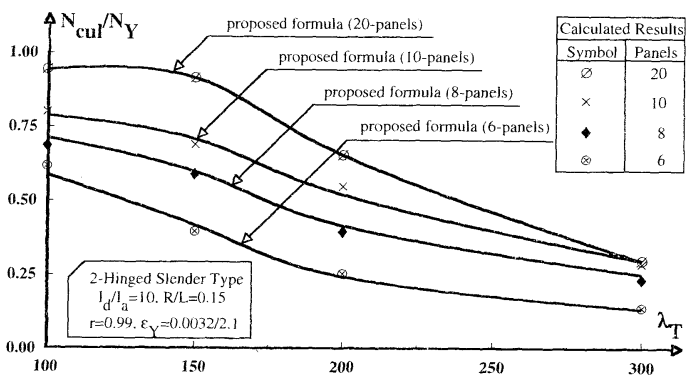

Fig.13 Comparison of Calculated Strength with Predicted One for 2-Hinged Type.

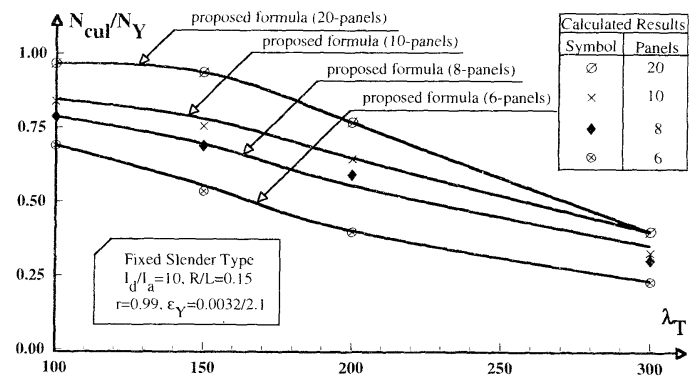

Fig.14 Comparison of Calculated Strength with Predicted One for Fixed Type.

the proposed reduction factor for the interactive strength, in which the 20-panel system is adopted as the standard arch bridge and it is analyzed with the ultimate strength approach. The symbolized marks indicate the $\phi$ calculated with the ultimate strength analysis for 10,8- and 6-panel systems. The accuracy of this formula demonstrated in Fig.13 for 2-hinged deck-type arch bridge structures and Fig.14 for fixed ones. The correlation is considered satisfactory for practical purpose. It may be concluded that the interactive strength concept proposed herein gives results be sufficiently accurate for practical applications.

When structures are designed by the limit states approach based on ultimate strength, a design is considered to be satisfactory if the calculated strength is equal to or greater than the required 
strength for the factored load. In the approach, an important essential is how to provide the criterion on the required strength. The extensive numerical results for the local failures examined herein may permit to propose two kinds of criteria for the slender arch rib type of stiffened deck arch bridge structures. One is that the component arch ribs of the bridge structure are proportioned not so as to fail prematurely by local member bucklings. In this case, the criterion can be specified as the $\phi$ should be equal or more than unity. It is proposed to use the $\lambda_{l, c r}$ practically formulated by Eq. (12). Another is the case of which the end panel buckles locally before the overall ultimate load is reached, leading to a reduction in the load capacity. Therefore, the required load capacity of members in this case is povided by reducing the ultimate overall stability capacity with the strength reduction factor $\phi$, and should be slightly greater than the member force induced by the factored applied loads. In this approach, if using the proposed factor $\phi$, no interactive instability analysis needs to be performed on the deck type arch bridge structure.

\section{CONCLUSIONS}

A design requirement for inplane stability strength of deck-type steel arch bridges has been presented. This requirement was derived within a range of conventional structural dimensions of steel arch bridges. From this investigation the following conclusions can be reached mainly :

(1) The ultimate strength for overall instability of a deck type arch bridge structure can be related to that of an equivalent arch using the integrated bending moment of the bridge structure defined by Eq. (3) and the equivalent slenderness ratio parameter defined by Eq. (4).

(2) The design criteria proposed previously for an arch are then modified so as to provide the criteria be applicable to the deck type by substituting Eqs. (3) and (4) into Eqs.(2). The proposed formula can provide good estimate of the ultimate strength for overall instability of deck type arch bridge structures.

(3) The effect of local member buckling in a panel on the ultimate strenght of the deck type arch bridge structures is examined for a widely various range of structural parameters.

(4) A practical prediction formula for the reduction factor is proposed by Eq. (12), based on the calculated results of the ultimate strengths for slender rib types of arch bridge structures. The key step in establishing the criteria is to relate the standard ultimate strength for overall instability to the ultimate strenght for interactive instability of the local member buckling, using a reduction factor defined by Eq. (10). Then, multiplying this factor by the standard ultimate strength, the associated loss of the strength by the local member buckling can be evaluated for deck-type arch bridges. It has been demonstrated that the ultimate interactive stability strength can be determined fairly accurate by the criteria and no interactive instability analysis needs to be performed on the deck-type arch bridge structures.

Additional studies on the design requirement for the deck-type steel arch bridge structure with continuous stiffening girders and trussed Langer ribs remain to be examined. Works on developments of such design requirements for the arch bridge systems are in progress by the writer.

\section{ACKNOWLEDGEMENT}

The writers wish to thank Messrs. T. Shimozato, K. Shutoh, Y. Nagamine and N. Taguchi of the Department of Civil Engineering at University of Ryukyu for drawings and typings.

\section{REFERENCES}

1) Shinke, T., Zui, H. and Namita, Y. : Analysis and experiments on in-plane load carrying capacity of arches, Proc. of JSCE, No.267, pp.34 52, 1975 (in Japanese).

2) Kuranishi, S. and Yabuki, T. : Some numerical estimations of ultimate in-plane strength of two-hinged steel arches, Proc. of JSCE, No.287, pp.155 158, 1979.

3 ) Kuranishi, S. and Yabuki, T. : Ultimate strength design criteria for two-hinged steel arch structures, Proc. of JSCE, Structural Eng./Earthquake Eng., Vol.1, No.2, pp.229s 237s, 1984.

4) Yabuki, T., Vinnakota, S. and Kuranishi, S. : Fixed-end restraint effect on steel arch strength, Journal of Stuructural Engineering, Proc. of ASCE, Vol.112, No.4, pp.653 664, 1986.

5 ) Yabuki, T., Lu, L.W. and Kuranishi, S. : An ultimate strength design aid for fixed-end steel arches under vertical loads, Proc. of JSCE, Structural Eng./Earthquake Eng., Vol.4, No.1, pp.115s 123s, 1987.

6) Kuranishi, S., Sato, T. and Otsuki, M. : Load carrying capacity of two hinged steel arch bridges with stiffening deck, Proc. of JSCE, No.300, pp.121 130, 1980.

7 ) Wen, R.K. and Medallah, K. : Elastic stability of deck-type arch bridges, Journal of Structural Engineering, ASCE, Vol.113, No.4, pp.757 768, 1987.

8) Yabuki, T. and Kuranishi S. : In-plane ultimate strength of deck-type fixed-end arch bridges, Proc. of JSCE, Structural Eng./Earthquake Eng. Vol.6, No.2, 375s 368s, 1989.

9) Fukumoto, Y., ed. : Guidelines for Stability Design of Steel Structures, JSCE, 1987 (in Japanese).

10) Galambos, T.V., ed. : Guide to Stability Design Criteria for Metal Structures, 4th Edition, SSRC, 1988.

11) Yabuki, T. and Kuranishi, S. : Ultimate strength design of 
steel arch bridge structures, IABSE Proc. P-84/85, IABSE PERIODICA, pp.57 64, 1985.

12) Shinke, T., Zui, H. and Nakagawa, T. : Inplane load carrying capacity of 2-hinged arches with a stiffening girder, Proc. of JSCE, No.301, pp.47 59, 1980 (in Japanese).
13) Japan Road Association : Japanese Highway Bridge Specification, 1990 (in Japanese).

14) Nishino, F., ed. : Design Code of Steel Structures-PART A; Structures in General-, JSCE, 1987 (in Japanese).

(Received December 17, 1992)

上路式鋼アーチ橋の強度評価について

矢吹哲哉・倉西 茂

本研究では，先ず上路式鋼ア一千橋の面内終局強度について広範囲にわたるパラメト リック解析を行い，その特性を検討した．次にその結果に基づいて, 全体座屈及び局部 座屈に関する実用強度算定法を提案した，全体座屈については等価ア一チを提案するこ とにより, 又, 局部座屈についてはパネル内限界細長比と全体座屈に対する強度低減係 数を導出することにより，実用強度の評価を行った，最後に，本手法を用い上路式鋼 2-ヒンジ及び固定アーチ橋の面内終局強度を算定し, 本法の算定精度を確認した. 